\title{
NECESSITY OF IMPROVEMENT OF FOREIGN LANGUAGE TEACHING IN THE SLOVAK REPUBLIC
}

\author{
MONIKA ŠTRBOVÁ \\ Department of Sociology, Constantine the Philosopher University in Nitra \\ B. Slančíkovej 1, Nitra 94901 Slovakia \\ Email address: mstbova@ukf.sk \\ ORCID: https://orcid.org/0000-0001-9757-3224 \\ MARCELA ŠARVAJCOVÁ \\ Department of Sociology, Constantine the Philosopher University in Nitra \\ B. Slančíkovej 1, Nitra 94901 Slovakia \\ Email address: msarvajcova@ukf.sk \\ ORCID: https://orcid.org/0000-0002-1441-6993
}

\begin{abstract}
Aim. The aim of the research study was to investigate the opinions of the Slovakian secondary school foreign language teachers and learn about their views on the system of education in the field of enhancement of teachers' professional qualifications.

Methods. To perform the study, the method of focus group was used.

Results. The results of the presented research show the differences between the perception of foreign language education in the past and how it appears today through the views of a selected number of foreign language teachers in Slovakia. The pivotal role is played by the technological skills of the students and their ability to use information technologies instructed in foreign languages. The research results also indicate the possibilities of teachers to get in direct contact with the target foreign language as a part of their professional development. The research participants also specified the factors that they considered the most influential in the process of foreign language learning.

Conclusion. The purpose of the article is to discuss the urge to achieve highly professional foreign language education in today's technological society. As shown by the results obtained from the focus group, the teachers/participants agreed on a single highly impactful factor: family.
\end{abstract}

Key words: education, foreign languages, teacher, information-communication technologies 


\section{INTRODUCTION}

Tn the European context, high quality education and multilingualism play key Iroles in foreign language education at institutions and the process of international integration. Although knowledge is mostly developed through the system of schooling, the role of foreign language teachers' education appears equally important (Chernysh, Vaseiko, Kaplinskiy, Tkachenko, \& Bereziuk, 2020). Contemporary education is different than it used to be in the past. As Birsen Tütüniş and Duygu Yalman (2020) state, today's generation of students is more intelligent and they master different types of knowledge and skills. Hence, it is necessary to teach them differently, especially with regard to foreign languages. The research study emphasises the importance of active participation of the whole class in a purposeful communication instead of drills, linguistic knowledge, and methodology of teaching. Moreover, foreign language syllabus in most of the European countries emphasises achievement of communicative skills as one of the highest priority. Although foreign language communication skills are defined through four main areas of communication (listening, speaking, reading, and writing), in reality, foreign language education mainly draws attention to teaching grammar and theoretical linguistic knowledge.

Without a doubt, many improvements have taken place since the year 1989 in Slovakia. The textbook market has developed; the boundaries with the western countries have been open and teachers have received support to increase their qualifications, improve their language skills, methodological competencies, and lead the process of instruction in accordance with the updated syllabus. There are many well-educated students at grammar schools who have good knowledge of one foreign language, and they are able to think in the foreign language, speak the language fluently, write correctly, and understand the written text (Buntová, 2010). The ability to communicate in one foreign language is a global competence also expected at labour market. The systems of commerce and technology are interrelated: as the research study displays, foreign language knowledge and the ability to speak one or two foreign languages are highly supported in the system of education, also in the system of education for global citizenship (Stein-Smith, 2018).

Secondary grammar school education is crucial for the job opportunities at labour market. It is massively important to apply modern and novel methodologies in teaching as well as in various syllabus designs. It is often necessary to re-design or change foreign language syllabus based on the needs of the labour market. Specifically, it is also important to take foreign language teachers' perception of needs into consideration. Generally, it is advised to support teacher's life-long learning as well as natural contact with a foreign language and its culture. It is alarming to find out that young teachers feel the lack of support and stimuli from the state authorities. In Slovakia, the problem occurs the most when teachers of English are considered. There is still a great demand for professional and fluent English speakers in the post-communist countries such as Slovakia. 
Nowadays, an increasing number of European countries struggles with the need to reform the approaches and instructions within the system of foreign language education. The EU agreements from 2002 signed in Barcelona agreed on important steps in the process of enhancement of learning at least two foreign languages at school, starting at rather early age.

Based on the results by Eurobarometer, $98 \%$ of upper secondary school students learn one or more foreign languages, from which $20 \%$ learn one foreign language and 78\% learn two foreign languages. Compared with the European Union, the considered data is above the average values. The most common foreign language is English (96.5\%), followed by German (53.6\%). Although the ability to communicate in both forms, written and oral, express ideas and present them in a foreign language is one of the principles of successful foreign language communication in business or in personal life, $20 \%$ of teachers are not satisfied with how the students are prepared to communicate in the foreign language. There are several factors that influence how the students who leave secondary schools are able to communicate in the foreign language; either teachers appear not to be qualified enough to teach (many of the teachers are non-qualified to teach a foreign language), or traditional teaching instruction and methods that are used in the process are not efficient. Many methods still emphasise grammatical structures and drills instead of strategic competence enhancement (Hall et al., 2019).

Although officially learners start at the age of eight, in Slovakia the number of fluent speakers of English is disappointing. Apparently, some elements of the system of foreign language education are insufficiently developed. Even though the number of English speakers has been rising lately, compared to other western European countries it is below the average. Although Slovak secondary grammar schools students study English since very early age (i.e. at the age of eight), many of them struggle to speak fluent English. Consequently, they have fewer opportunities to get a job in a foreign country or in a company demanding active communication in a foreign language. As established by the secondary grammar schools or secondary vocational school syllabus, all students leaving schools have studied one foreign language for 11 years. The teachers do not apply for international mobility programmes. Obviously, several reasons for that exist; firstly, there is a problem with teachers traveling abroad; secondly, financing such a mobility programme may be a financial burden for a common public school.

\section{METHODS}

The aim of the study was to investigate the opinions of the secondary school foreign language teachers in Slovakia and find out their views on the specific part of the system of education in the field of enhancement of teachers professional qualifications. The aim of foreign language education in the European environment is to offer foreign language education in two non-native languages; thus, the mobility of EU citizens and the job opportunities in the European educational environment and competitiveness in the wide variety of 
sectors should be higher. The essence of foreign language education is to ignite joy of learning a foreign language and utilise positive approach and eagerness of children to learn (Skabela, 2014).

To perform the study, the method of focus group was used. It is usually applied in various research fields or when examining different social problems. Although, it sometimes serves as an additional research technique, for the purpose of this research it served well as the effective method of examination. Considering the field and the setting of our research, the method of focus group was best to achieve the research objective. Mostly, this method is used to reveal attitudes, experiences and opinions or responses of individuals participating in research studies.

The focus group was organised according to a precise scenario, which was constructed at the Department of Sociology; the entire process was recorded with the use of a voice recorder (duration of 90 minutes) and is available at this department. The participants entered the selected questions in a default sheet (when, for example, it was necessary to sort the selected options according to preference, etc.). The answers were evaluated manually on the basis of pre-selected categories and subcategories. These were:

- differences in education in the past and today;

- contact with foreign language;

- foreign language education support.

The study took place at the Department of Sociology at Constantine the Philosopher University in Nitra on January 13, 2020 as a part of the project whose contract number is APVV-17-0071. Foreign language teachers of secondary grammar and secondary vocational schools were the research participants.

This focus group was attended by teachers from secondary schools involved in project cooperation - specifically secondary schools from the Nitra region (who also participate in other activities within the project). These specific schools were represented in the discussion by their foreign language teachers. As seen in Table 1, there were 8 women from 2 types of schools - a grammar school and a secondary vocational school. Selected teachers are graduates of the universities of Nitra, Bratislava and Banská Bystrica.

Table 1

Research participants

\begin{tabular}{cclc}
\hline Number & Age & \multicolumn{1}{c}{ Type of school } & Years of teaching \\
\hline 1 & 45 & secondary vocational school & 20 \\
2 & 45 & secondary vocational school & 20 \\
3 & 45 & secondary vocational school & 20 \\
4 & 47 & secondary vocational school & 25 \\
5 & 28 & secondary grammar school & 3 \\
6 & 28 & secondary grammar school & 3 \\
7 & 47 & secondary grammar school & 20 \\
8 & 63 & secondary grammar school & 40 \\
\hline
\end{tabular}

Source: own research 


\section{RESULTS AND DISCUSSION}

\section{Differences in education in the past and today}

The participants were asked the introductory question about the main differences between the foreign language education in the past and present. As seen in Figure 1, their responses were divided into four main circles.

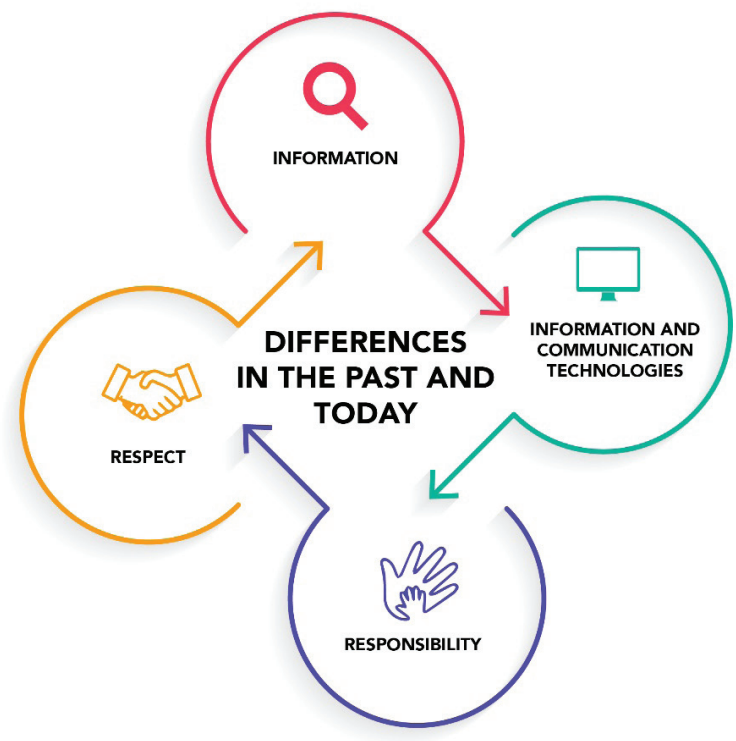

Fig. 1. Differences in the past and today.

Source: own research, 2021

The greatest and the most essential change that the participants named was the technological skill of the students today. The Internet is a medium that students use on a daily basis. Students use it on daily bases. The generation of their parents and teachers grew without such technologies as mobile phones, tablets and laptops. Technological development has been growing rapidly and technologies influence life of individuals and society as a whole. Even though the trend is to implement modern technologies into every aspect of education, it is not accepted by various levels of the educational system. As observed technologies have become a natural part of nowadays lives of young people, therefore, it is essential to consider their implementation into the system of everyday education. The positive aspects of the technologies are obvious; however, the negative influence is also taken into account, mainly by the experienced generation of teachers. They often predict negative influence or even harmful consequences of the influence.

As Alina Padurean (2015) claims, there are several positive arguments that support the use of technologies when teaching foreign languages: 1) students prefer them; 2) they encourage the use of English as the language of commu- 
nication, 3) there is a high variety of teaching materials availbale online; 4) opportunities to speak with others appear; 5) all four skills are developed. Hence, there is a great need to use technologies in education. Obviously, the younger teachers who use technologies naturally gradually substitute their older colleagues. According to Kadek Eva Krishna Adnyani, I Wayan Adnyana and Ni Nyoman Murniasih (2019), the use of technologies may possibly prepare the students for their future careers. Moreover, integration of technologies is an effective way to connect with the students of various learning styles and may also provide the environment to cooperate with the students in small groups and improve interaction. Every participant of the education gradually integrates technologies into their professional practice. Apparently, it is the teachers who need to learn how to work with technologies and learn to implement them into the educational process based on the requirements of the contemporary information society. It is necessary to support educational institutions to transform and use modern technologies to develop critical thinking and flexibility in problem-solving contexts.

Importantly, as technologies develop, people communicate and reach for information directly. It is one of the most important tool of interaction used by the people in the $21^{\text {st }}$ century (Nesip Öğün, Öznacar, Tatar, \& Debeş, 2020). Technologies constitute a quick and easy source of information and students of the young generation can get access to a much greater amount of information compared to the older generation of students. As the results show, the participants also confirmed the great variety of accessible information, however, the students, as the participants say, often approach the Internet sources without any critical evaluation and simplify them. School, as Vural Hoşgörür and Pinar Bilasa (2009) claim, has to be open to new improvements. Success often depends on the professionalism of teachers who have to acquire the values, characteristics and behaviour of information society. If students focus on the assigned topics and teachers support them in critical thinking, students' creativity can be improved. Student-centred teaching has become the central point of information society. Students should be inspired to continue working with heard and read text. In modern schools, teachers are encouraged to criticise students constructively, to inspire them, to support their creativity, and to avoid methods based on drills (Hoşgörür \& Bilasa, 2009). This is the role of a modern $21^{\text {st }}$ century teacher: to teach children and young people to work with information, teach how to select it, and rationally and creatively evaluate its vailidity.

Moreover, as the teachers/participants claim, students are less responsible compared to their past counterparts. As Yakovleva, Savvina and Popova (2020) state, responsibility is formed in the social family atmosphere. The participants stated that students used to pay more respect to their teachers in the past compared to today's generation. Ali Ibrahim and Wafaa El Zataari (2019) present similar results in their study showing three dimensions of a healthy status in teacher-student relationship that were confirmed as negative. The results also included negative occurrence of the following variables between students and 
teachers: 1) cooperation and reciprocity; 2) respect, love, care; and 3) balance of power between students and teachers. As the results showed, the students from the research considered school frustrating and did not develop the sense of loyalty and fellowship.

\section{Contact with foreign language}

Foreign language teacher should be naturally interested in the language they teach. Unfortunately, their presentation of the language is oftentimes very robotic and artificial. Often, the teachers have no opportunities to communicate in the language outside of the classroom. As all teachers/participants agreed, even though they had accomplished university education and had achieved full qualification, they have not communicated in the foreign language since their graduation. One of the questions was how they improve their language skills and how they communicate in the language. As all teachers/ participants agreed, even though they had accomplished university education and had achieved full qualification, they have not communicated in the foreign language since they graduated. One of the questions was how they improve their language skills and how they communicate in the language. Figure 2 presents their contact with the foreign language. Two of the participants had a non-Slovak spouse, leading to everyday communication in a foreign language. The rest of the participants, as they claimed, had no opportunities to speak the language. They only read English books and they occasionally watch a movie in English without dubbing. Other than that, they claimed they have no other contact with the language. The youngest research participant, who recently graduated, noted that her knowledge of English and the skills have not improved since, and together with her classmates, they all have seen no improvement. The system of education does not provide enough opportunities to develop the language. Apparently, there is a huge difference between the teachers working in the secondary grammar schools and those in the secondary vocational schools. 


\section{Contact with foreign language}

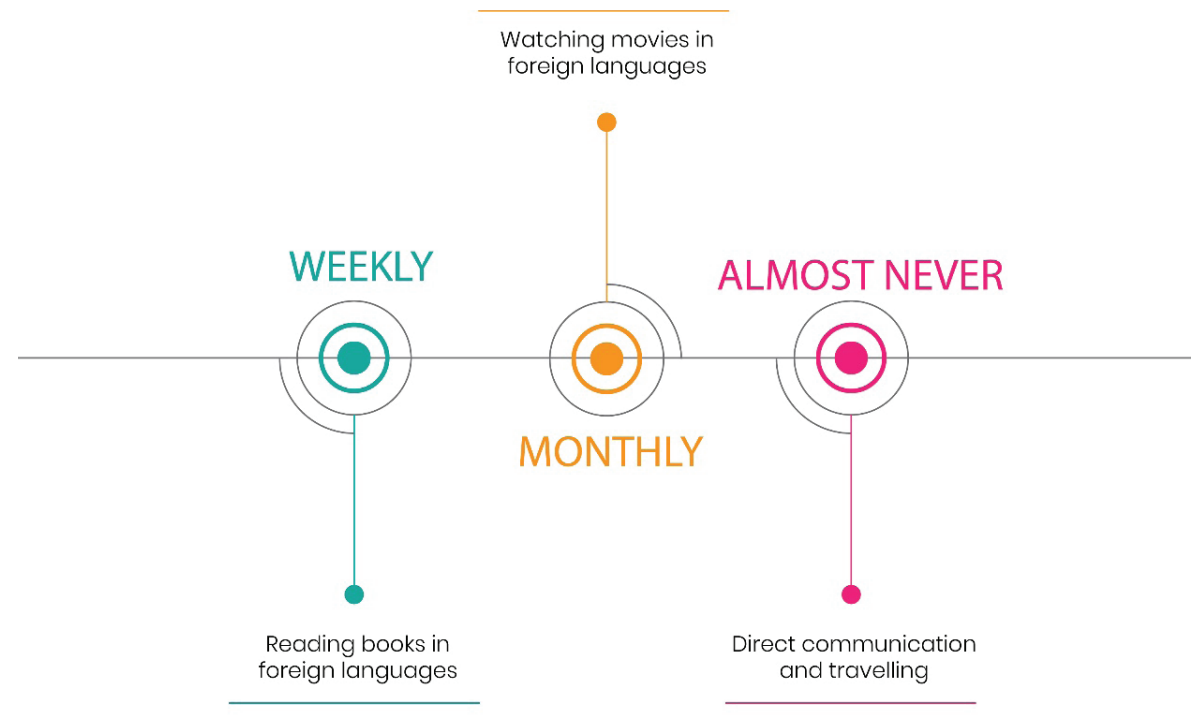

Fig. 2. Contact with foreign language.

Source: own research, 2021

Travelling abroad is extremely important for foreign language teachers and their professional growth as one of the systematic support systems of progressing in foreign language skills. Abroad, teachers get to know the culture of the language they teach. the system of international mobility is one of the effective methods of acquiring necessary skills and competencies in foreign languages. Being a part of the culture of the target language for a certain time during the pre-service time of teachers ' training is often crucial. It promotes desired language skills and direct touch with the target culture. In our research, one of the aims was to find out if the central educational authorities in the country recommend and systematically support international mobility as a method of increasing teachers' professional development. The international measurement (Organisation for Economic Co-operation and Development [OECD], 2013) informed how teachers of various subjects are supported to travel abroad. More than half of the foreign language teachers visited foreign countries as a part of their professional growth $(56.9 \%)$ compared to the teachers of other subjects $19.6 \%$. In Spain and in Iceland, more than $70 \%$ of foreign language teachers visit the country of the language they teach. Foreign language teachers need to practise and improve the language they teach. Equally important is 
the direct touch with the culture of the target country. It is one of the ways to gain important contact with the culture of the country and share it with their students. However, in reality more than $40 \%$ of the selected teachers/research participants have never participated in any study programme designed for language teachers. It may have an influence on the students and the quality of education they may get in the future. Less than $40 \%$ of the foreign language teachers from the selected countries (Croatia, Portugal, Romania, and Slovakia) have participated in a study programme for teachers of foreign languages (Európska komisia/EACEA/Eurydice, 2017). Nowadays, education is extremely demanding in terms of emotional and cognitive development. Although the teachers try their best, students may recognise their uncertainty in language. As Zdena Král'ová and Eva Malá (2018) claim, lack of exposure to the target language and culture has a great negative impact on both groups, the teachers, and their students. Scientists describe it as a foreign language anxiety. Obviously, teachers who do not encounter foreign language on a regular basis and do not educate themselves will not solve their pronunciation problems and consequently will not become good teachers in a long term (OECD, 2013). In our research, the assumption is that if teachers do not have the ability to use the target language out of their classroom, it may have a negative impact on the students they teach.

Moreover, the research participants named one more problem in the field of foreign language education: many teachers of English are not fully qualified to teach. The percentage of non-qualified teachers among English teachers in Slovakia is particularly high. Presumably, relationship of children to a school subject also depends on the level of professionalism of the teachers. Knowledge and development of foreign language skills at secondary grammar or vocational schools might also be influenced by the low degree of professionalism of some teachers. As the participants claim, it is sometimes the case that teachers of secondary schools need to teach the syllabus of the lower secondary schools because the students come to the higher level of education lacking adequate knowledge and skills. Teachers identified several essential critical issues in the system of foreign language education in Slovakia. It appears that systematic communication between the authorities of the lower and the upper secondary schools is absent. Lack of communication is noticeable between the two different educational state policies: one serves the lower and the other the upper secondary education; they often decide without any further communication or critical discussion. Furthermore, the level of education also differs very much when specific regions are compared.

\section{Foreign language education support}

Although the participants identified many problems, they also named several factors that help children to improve. Thse are rooted in one common influence - family. Considerable involvement of parents in the process of education is one of the essential strategies in successful academic achievements (Driessen, 2019). The role of parents is considered to be crucial in the success of 
their children at school; the behaviour of parents has crucial impact on child's self-perception, its intellectual abilities and the value of education. Strategies of educational socialisation of parents function on two mutually interrelated levels. First level begins before the formal school education (reading storybooks) and the second is related to the involvement of parents in cognitive socialising strategies by supporting the development of intellectual abilities of their children (Bempechat \& Shernoff, 2012).

Figure 3 presents how the participants viewed the most effective help and support in foreign language education. They claim that parents speaking the language very well and being able to help their child with homework is the most significat aspect of the support. Very early exposure of children to a foreign language brings high quality education and skills in that language. Many parents are highly motivated to assist the education of their children because they want the children to obtain the relevant skills and not miss what they themselves lacked when they were children (Celaya, 2012; Forey, Besser, \& Sampson 2016). As Eleni Korosidou, Eleni Griva and Olena Pavlenko (2021) claims, many researchers noticed that foreign language abilities increased at early age when the parents were interested in the issue of literacy. Oftentimes, the interest of parents depends directly on their socio-economic status and their education; the research by Gail Forey et al. (2016) in Hong Kong points out that even the parents representing lower social status understand the relationship between the ability to speak a foreign langue and one's professional success and prosperity in life. That is why such parents are also motivated to support their children to learn a foreign language. The most frequent approach to supporting their children in language education is to send the children to language schools or pay private teachers and lecturers. However, as most of the research studies show, both the socio-economic status of parents and their level of education have a great influence on their predisposition to support their children at educational activities (Driessen, 2019; Korosidou et al., 2021).

Numerous scientists support the idea of early age foreign language acquisition through reading picture stories or various types of other stories for older children (Davidheiser, 2007, Kováčová Švecová \& Smalley, 2020). This kind of learning is possible also in the families when parents do not speak fluent English or whose level of English is very low.

The results obtained by Linda M. Wallinger (2000) suggest that all foreign language teachers across all the levels consider homework an inevitable part of the process of learning a foreign language. However, there are no data provided that would confirm the importance of homework in language education because it is not confirmed whether teachers check back the correct responses and correctness of the tasks they assign to be done at home.

Nowadays, children have a lot more opportunities to listen to a foreign language compared to the past. They are frequently exposed to languages through television, social media and by attending private language lessons. This is helpful to language teachers; it does, however, put more pressure on the teachers to learn more themselves. 


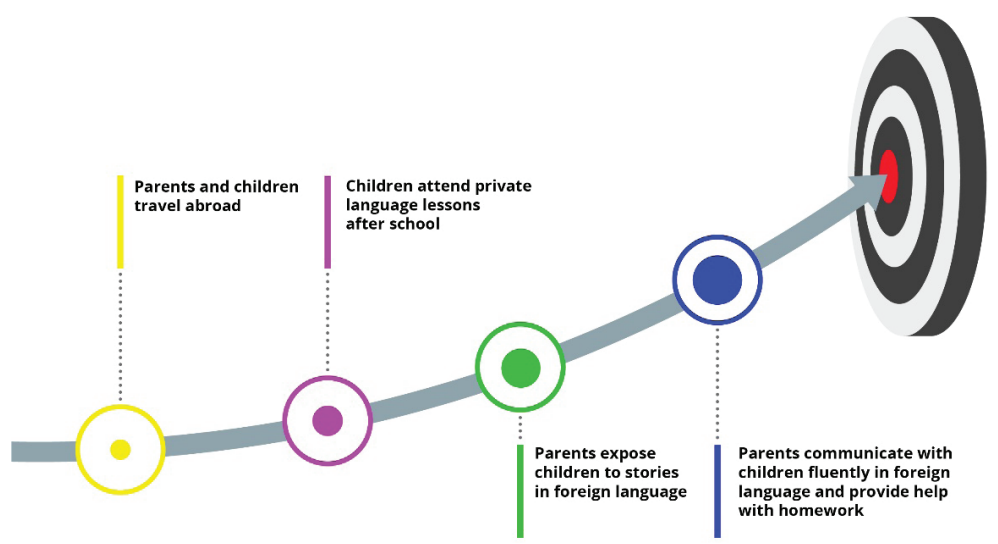

Fig. 3. Support and help in learning foreign languges.

Source: own research, 2021

\section{CONCLUSIONS}

The achieved standard of living and quality of life in Europe relates closely to the increasing level of education and language skill development. It is important to realise that complex foreign language education in Europe should be implemented at all levels of schooling and in the system of lifelong learning. The European dimension of language education puts great emphasis on the need to learn foreign languages. Moreover, the ability to speak foreign languages is related to the improved status on the labour market. Foreign language skills are some of the most influential factors in competitiveness on the labour market in the European multicultural environment. Generally, investment to improveme one's communication skills of teachers as well as to foreign language education as such, it is often directly reflected in the socio-economic environment of the European countries (Varečková \& Pavelková, 2018). The research results showed certain failures in the support system for educational development of teachers. Moreover, the teaching positions are underfunded in Slovakia, which is the reason why many highly professional teachers have moved on to other jobs.

Apparently, the process of teacher support by the system is underestimated and students suffer consequences. Motivation to learn a foreign language and to begin very early at the primary level of education is often a burden for many parents. Students as well as teachers have a great opportunity to develop digital competencies and use the possibilities provided by contemporary information and communication technologies. However, the role of the family as a factor of language improvement is also crucial. Calling for the need of 
interactive relationship between the school and the family was confirmed also in our research. Usually, respect for teachers that children show at school is interiorised earlier in the family environment. Moreover, the support of schooling and learning in the family is important for teachers to earn respect. The significant influence of technologies on foreign language education is also considered. Teachers cannot ignore the existence of modern technologies and are expected to teach their students how to develop competencies related to them.

Although the research study was carried out exclusively in Slovakia, very similar problems with foreign language education also appear in other European V4 countries as well as other non-English speaking countries. The research was limited in terms of the number of participants and the qualitative approach. Further research should encompass quantitative methods.

\section{ACKNOWLEDGEMENTS}

The Slovak Research and Development Agency supported this work under the contract No. APVV-17-0071.

\section{REFERENCES}

1. Adnyani, K. E. K., Adnyana, I, W., \& Murniasih, N. N. (2019). Teacher and students' perception on using Kahoot! for English learning. Proceedings of the 3rd International Conference on Innovative Research Across Disciplines (ICIRAD 2019), 62-67.

2. Bempechat J., \& Shernoff D. J. (2012). Parental influences on achievement motivation and student engagement. In: S. Christenson, A. Reschly, \& C. Wylie (Eds.), Handbook of research on student engagement. Boston: Springer. doi:10.1007/978-1-4614-2018-7_15.

3. Buntová, Z. (Ed.). (2010). Aktuálne problémy vo vyučovaní cudzieho jazyka u študentov trnavských vysokých škôl nefilologického zamerania [Contemporary problems of foreign language education of the Trnava region students of non-philological studies]. Trnava: Filozofická fakulta TU.

4. Celaya, M. L (2012). “I wish I were three!” Learning EFL at an early age. In: M. González \& A. Taronna (Eds.), New trends in early foreign language learning: The age factor, CLIL and languages in contact. Bridging research and good practices. (pp. 2-12) Newcastle upon Tyne: Cambridge Scholars Publishing.

5. Chernysh, V. V., Vaseiko, Y., Kaplinskiy, V., Tkachenko, L., \& Bereziuk, J. (2020). Modern methods of training foreign language teachers. International Journal of Higher Education, 9(7). 332-344. doi.org/10.5430/ijhe.v9n7p332.

6. Davidheiser, J. C. (2007). Fairy tales and foreign languages: Ever the twain shall meet. Foreign Language Annals, 40(2), 215-225. doi:10.1111/j.1944-9720.2007.tb03198.x.

7. Driessen, G. (2019). Parental involvement, parental participation, parent-school-community partnerships. Encyclopedia. Retrieved December 14, 2020, from: https://encyclopedia.pub/279

8. Európska komisia/EACEA/Eurydice, (2017). Klúčové údaje o vyučovaní jazykov v európskych školách - 2017 [Key data on teaching languages at schools in Europe - 2017]. Eurydice Report. Luxembourg: Publications Office of the European Union.

9. Forey, G., Besser, S., \& Sampson, N. (2016). Parental involvement in foreign language learning: The case of Hong Kong. Journal of Early Childhood Literacy, 16(3), 383-413. doi:10.1177/1468798415597469.

10. Hall, R., Drál' P., Fridrichová, P., Hapalová, M., Lukáč, S., Miškolci, J. \& Vančíková, K. (2019). Analýza zistení o stave školstva na Slovensku: To dá rozum [Analysis of the current situation on the education system in Slovakia. That makes sense]. Bratislava: MESA. Retrieved December 6, 2020, from: https://analyza.todarozum.sk/docs/391341001ol1a/. 
11. Hoşgörür, V., \& Bilasa, P. (2009). The problem of creative education in information society. Procedia - Social and Behavioural Sciences, 1(1), 713-717. doi:10.1016/j.sbspro.2009.01.125.

12. Ibrahim, A., \& Zataari, W. E. (2019). The teacher-student relationship and adolescents' sense of school belonging. International Journal of Adolescence and Youth, 25(1), 382-395. doi:10.1080/ 02673843.2019.1660998.

13. Korosidou, E., Griva, E., \& Pavlenko, O. (2021). Parental involvement in a program for preschoolers learning a foreign language. International Journal of Research in Education and Science, 7(1), 112-124. doi:10.46328/ijres.1219.

14. Kováčová Švecová, Z., \& Smalley, D. (2020). Slovak as a foreign language - teaching language through stories and fairy tales. In: L. Gómez Chova, A. López Martínez, \& I. Candel Torres. (Eds.), Proceedings of $12^{\text {th }}$ International Conference on Education and New Learning Technologies (EDULEARN20) (pp. 5832-5836). IATED Academy.

15. Král'ová, Z., \& Malá, E. (2018). Non-native teachers' foreign language pronunciation anxiety. International Journal of Technology and Inclusive Education, 7(2), 1322-1330. doi:10.20533/ ijtie.2047.0533.2018.0161.

16. Nesip Öğün, M., Öznacar, B., Tatar, A., \& Debeş, G. (2020). Information technologies and reaching to information society. REICE: Revista Electrónica de Investigación En Ciencias Económicas, 8(16), 412-449. doi:10.5377/reice.v8i16.10708.

17. Organisation for Economic Co-operation and Development (2013). Teaching and Learning International Survey. TALIS 2013. Conceptual framework. Retrieved October 14, 2020, from https://www.oecd.org/education/school/TALIS\%20Conceptual\%20Framework_FINAL. pdf.

18. Padurean, A. (2015). Approaches to teaching literature in EFL classrooms. Journal of Romanian Literary Studies, 6, 195-200.

19. Skabela, R. (2014). Vyučovanie cudzieho jazyka na základnej škole pomocou aktivizujúcej metódy "živé obrázky" [Teaching foreign languages at primary schools through the activating method "still images"]. Bratislava: Metodicko-Pedagogické Centrum.

20. Stein-Smith, K. (2018). The U.S. foreign language deficit: Strategies for maintaining a competitive edge in a globalized world. Palgrave Macmillan. (Original work published in 2016).

21. Tütüniş, B. \& Yalman D. (2020). Teacher education and foreign language teacher professionalism in the $21^{\text {st }}$ century. International Online Journal of Education and Teaching, 7(3), 1168-1176.

22. Varečková, L., \& Pavelková, J. (2018). Importance of foreign languages in education process at universities. Revista Romaneasca Pentru Educatie Multidimensionala, 10(4), 294-306. doi. org/10.18662/rrem/89.

23. Wallinger, L. M. (2000). The role of homework in foreign language learning. Foreign Language Annals, 33(5), 483-496. doi:10.1111/j.1944-9720.2000.tb01993.x.

24. Yakovleva, A., Savvina, I., \& Popova, S. (2020). Students' responsibility and parents' attitude to them. In: O. M. Lubimova (Ed.), Proceedings of the International Scientific and Practical Conference on Education, Health and Human Wellbeing (ICEDER 2019) (pp. 44-49). ASSHER. doi:10.2991/iceder-19.2020.10. 